\title{
Hepato-biliopancreatic surgery in the elderly
}

\author{
V Pellegrino*, M Cannistrà, E Barcellona, S Vaccarisi, M Tortorella, M Canonaco, S Rizzuti, E De Marco, B Nardo
}

From de Senectute: Age and Health Forum

Catanzaro, Italy. 5-7 December 2009

\section{Background}

The HPB district tumour includes a high incidence between the 6th and the 8th decade of life.

ISTAT information from the 1st January 2009 confirm that people over the age of 65 represent $20.1 \%$ of the population.

In Calabria they represent $18,7 \%$ of the population, according to the national tendency.

\section{Materials and methods}

From November 2007 to October 2009,185 HPB patients from our Institute were observed and divided as follows: 39 for pancreatic tumours, 21for HCC;39 for neoplasm of the CBD, 41 for liver MTS; 45 for benign liver pathology.

\section{Results}

Operative mortality, disease - free survival and overall survival are very similar to the deducible information of the whole survey and they seem to be influenced by tactics and surgical technique.

As the elderly can present comorbidity, cognitive defects and less life expectancy, appropriate therapeutical options require a significant selection by the candidate for major resective surgery.

\section{Conclusions}

Our information indicates that seniority is not an aggravating risk in terms of outcome, not only by the significant patient selection but also by the surgeon experience and it doesn't condition major surgical options.

The HPB resective surgery, in selected elderly patients, can be done maintaining an acceptable morbidity and an appropriate survival level in terms of life.

Department of Surgery, Hepato-Bilio-Pancreatic Surgery and Organ

Transplant Unit (Head: Prof. Bruno Nardo). Annunziata Hospital, Cosenza, Italy
Published: 19 May 2010

doi:10.1186/1471-2318-10-S1-A23

Cite this article as: Pellegrino et al:: Hepato-biliopancreatic surgery in the elderly. BMC Geriatrics 2010 10(Suppl 1):A23.
Submit your next manuscript to BioMed Central and take full advantage of:

- Convenient online submission

- Thorough peer review

- No space constraints or color figure charges

- Immediate publication on acceptance

- Inclusion in PubMed, CAS, Scopus and Google Scholar

- Research which is freely available for redistribution

Submit your manuscript at www.biomedcentral.com/submit
C Biomed Central 